\title{
ANTIRADICAL ACTIVITY OF MUSTARD OIL DURING THE OXIDATION
}

\author{
A. Ukrainets, I. Radzievska, O. Melnyk, V. Pasichnyi \\ National University of Food Technologies
}

\begin{tabular}{l} 
Key words: \\
Oil \\
Oxidative changes \\
Kinetic parameters of \\
oxidation \\
Antioxidant activity \\
Tocopherols \\
Terpenes \\
\hline
\end{tabular}

Article history:

Received 11.05.2018

Received in revised form

24.05.2018

Accepted 08.06.2018

Corresponding author:

A. Ukrainets

E-mail:

npnuht@ukr.net

\section{ABSTRACT}

The problem of increasing the stability fat-and-oil products is associated with the study of the activity and action mechanism of natural antioxidants which are part of their composition. In order to predict the oxidative stability of fatand-oil products during storage, antioxidant activity and resistance to oxidation number of oils are determined. The flow of free radical oxidation was investigated at a temperature of $22 \pm 2^{\circ} \mathrm{C}$ and light access. The total effective antioxidants concentration in sunflower, nut, mustard, rapeseed, olive, corn oils and their antiradical activity has been determined by Tsepalov kinetic method. It is shown that the total antioxidants concentration in oils correlates with the total content of tocopherols, which act as inhibitors of chain processes. The dependence of the parameters $\mathrm{k} 2$ and $\mathrm{k} 7$ of the oxidation reaction with molecular oxygen, which characterizes the antioxidant activity of the oils, is determined. It is established that themustard oil slowly accumulates hydroperoxides in the auto-oxidation reaction and has a high total concentration of antioxidants at a level of $25,6 \cdot 103 \mathrm{~mol} / \mathrm{g}$.

It is shown that the amount of antioxidant activity in pressed mustard oil predominates over the investigated oils, regardless of their previous refining degree. The anti-radical properties of mustard oil are explained by the presence of antioxidants of the phenolic nature: $\alpha$-pinene and 1, 8-cineole. These antioxidants belong to the class of biologically active substances that bind free radicals, prevent the accelerated oxidation of lipids, and the formation of undesirable oxidation products. The established values of the total effective concentration of antioxidants can be used to predict the oxidative stability of the oils during storage.

DOI: $10.24263 / 2225-2924-2018-24-3-21$

\section{АНТИРАДИКАЛЬНА АКТИВНІСТЬ ГІРЧИЧНОЇ ОЛІЇ В УМОВАХ АВТООКИСНЕННЯ}

\author{
А.І. Українець, І.Г. Радзієвська, О.П. Мельник, В.М. Пасічний \\ Національний університет харчових технологій
}

Проблема підвищення стійкості олієжирових продуктів пов 'язана з дослідженням активності і механізму дії природних антиоксидантів, щэо входять 
до їх складу. 3 метою прогнозування окиснювальної стабільності олієжирових продуктів при зберіганні визначено антиоксидантну активність і стійкість до окиснення ряду рослинних олій. Перебіг вільнорадикального окиснення досліджено за температури $22 \pm 2^{\circ} \mathrm{C}$ і доступі світла. Кінетичним методом Цепалова встановлено сумарну ефективну кониентрацію антиоксидантів сонямникової, горіхової, гірчичної, ріпакової, оливкової, кукурудзяної олій та їх антирадикальну активність. Показано, щуо сумарна концентрація антиоксидантів рослинних олій корелює із сумарним вмістом токоферолів, які виконують роль інгібіторів ланџюгових прочесів. Визначено залежність параметрів $k_{2} i k_{7}$ реакції окиснення молекулярним киснем, яка характеризує антиоксидантну активність досліджуваних олій. Встановлено, щяо гірчична олія повільно накопичує гідропероксиди в реакції автоокиснення та відзначається високою сумарною концентращією антиоксидантів на рівні $25,6 \cdot 10^{3}$ моль/2.

3'ясовано, щзо за величиною антиоксидантної активності пресова гірчична олія переважає решту досліджуваних олій незалежно від ступеня їх попереднього рафінування. Віднайдено пояснення антирадикальних властивостей гірчичної олії через наявність антиоксидантів фенольної природи: $\alpha$-пінену та 1,8-ичинеолу. Ці антиоксиданти належсать до класу біологічноактивних речовин, які зв'язують вільні радикали, перешкоджають прискореному окисненню ліпідів $i$ утворенню небажсаних продуктів окиснення. Встановлені значення сумарної ефективної концентрації антиоксидантів можуть бути використані з метою прогнозування окиснювальної стабільності олій при зберіганні.

Ключові слова: олія, окисні зміни, кінетичні параметри окиснення, антиоксидантна активність, токофероли, терпени.

Поставновка проблеми. Гірчична олія - корисний продукт, який використовується з харчовою, лікувальною і косметичною метою. Здавна помічено, що олія з насіння гірчиці, на відміну від багатьох інших рослинних олій, більш стійка до окиснення. У зв'язку з повільним окисненням, гірчичну олію додають до інших олій для збільшення терміну їх придатності [1]. Згідно 3 вимогами ДСТУ 4598:2006 «Олія гірчична. Технічні умов» термін іiї зберігання становить від 10 місяців до 2 років.

Огляд останніх досліджень і публікацій. Для ефективного сповільнення процесу окиснення необхідним етапом $є$ дослідження його хімізму за різних способів ініціювання. Однією з перших сучасних схем окиснювальних перетворень жирів $\epsilon$ схема, запропонована W. Langenbeck [2]. В подальшому ця схема була підтверджена іншими вченими, але піддавалась незначному корегуванню і доповненню, зокрема у працях W. Pritskov [3]. Дослідженню розпаду гідропероксидів та аналізу продуктів окиснення присвячено працю [4]. Велику роль для розвитку сучасних уявлень щодо механізму самоокиснення олефінів киснем повітря відіграло створення академіком Н.Н. Семеновим i його школою теорії ланцюгових розгалужених реакцій [5]. Елементарний механізм рідкофазного окиснення вуглеводнів та їх похідних вивчають вітчизняні науковці харківської школи Ф.Ф. Гладкий, І.М. Демидов, О.М. Півень.

Однак, проблема захисту жирів від окиснювального псування, незважаючи на пильну увагу до неї з боку дослідників, далека від свого вирішення і по- 
требує додаткових досліджень, з урахуванням різноманіття харчових продуктів з високою часткою жирів [11; 12].

Мета дослідження: вивчення антиокиснювальної стабільності гірчичної олії (порівняно з іншими рослинними оліями) з точки зору теорії вільнорадикального окиснення вуглеводнів.

Викладення основних результатів дослідження. Кінетику окиснення нерафінованих (соняшникова, горіхова, гірчична, ріпакова) та рафінованих (кукурудзяна, оливкова) олій досліджено в умовах автоокиснення при темпеpaтурі $22 \pm 2^{\circ} \mathrm{C}$ за накопиченням у них гідропероксидів. Стійкість олій до окиснення оцінено за величиною періоду індукції.

Вміст токоферолів у досліджуваних зразках олій і хімічний склад легколетких компонентів гірчичної олії визначено методом рідинної хроматографії високороздільної здатності.

Для кількісного визначення характеристик інгібіторів реакції оксинення користуються графічним методом Цепалова, який заснований на побудові кінетичних кривих окиснення вуглеводнів. Глибина окиснення олій характеризується накопиченням гідропероксидів, вміст яких корелює з величиною пероксидного числа (рис. 1).

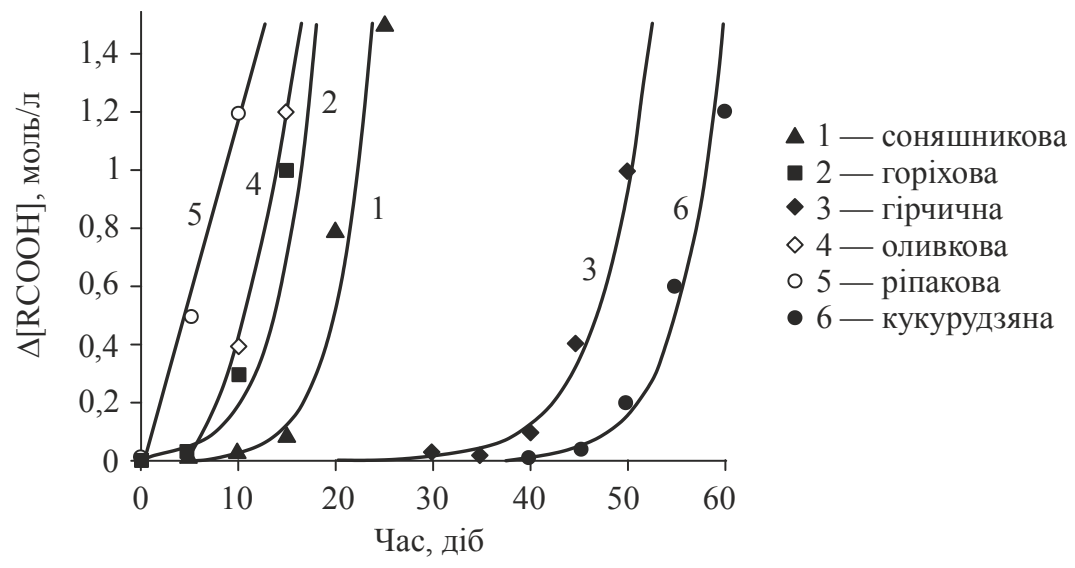

Рис. 1. Кінетичні криві накопичення гідропероксидів RCOOH в реакції автоокиснення при $22 \pm 2^{\circ} \mathrm{C}$

3 рис. 1 видно, що накопичення пероксидів при ініційованому окисненні відбувається 3 явно вираженими періодами індукції. Це свідчить про вміст антиоксидантних речовин в усіх досліджуваних оліях. Період індукції визначають графічно апроксимацією дотичних у початковій області для кожного зразка продукту. Швидкість окиснення олій визначають 3 наведених кінетичних кривих згідно з рівнянням:

$$
V_{i}=\frac{\Delta[\mathrm{RCOOH}]}{\Delta t} .
$$

Сумарний вміст антиоксидантів визначено з використанням рівняння: 


$$
\tau=\frac{f[\operatorname{In} \mathrm{H}]}{V_{i}}=\alpha \frac{m}{V_{i}},
$$

де $\tau$ - період індукції; $f$ - стехіометничний коефіцієнт інгібірування; [InH] сумарний вміст антиоксидантів у досліджуваній олії; $V_{i}$ - швидкість ініціювання; $m$ - маса зразка в мг.

Для оцінки антиоксидантних властивостей олій, крім визначення кількісного вмісту антиоксидантних речовин, важливо встановити їх антирадикальну активність, тобто визначити константи швидкостей реакцій подовження $k_{2}$ й обриванння $k_{7}$ ланцюгів окиснення загальноприйнятої моделі інгібованого окислення. Антирадикальна активність являє собою молекулярну характеристику сполук, здатних вступати в реакцію 3 вільним радикалом. Вона певною мірою відображує участь продуктів перетворення інгібітора в процесі окислення і визначає швидкість елементарної реакції загальноприйнятої моделі інгібованого окислення:

- подовження ланцюгів $k_{2}$ :

$$
\mathrm{RO}_{2}+\mathrm{RH} \rightarrow \mathrm{ROOH}+\mathrm{R}
$$

- обривання ланцюгів $k_{7}$ :

$$
\mathrm{RO}_{2} \cdot+\mathrm{InH} \rightarrow \mathrm{ROOH}+\mathrm{In} .
$$

Параметр $k_{2} / k_{7}$, що відповідає відношенню констант швидкостей реакцій подовження й обривання ланцюгів у періоді індукції, розраховано як $\operatorname{tg} \alpha$ кута нахилу прямої (рис. 2), побудованої в координатах рівняння:

$$
\Delta[\mathrm{RCOOH}]=\ln \frac{1}{1-t / \tau} .
$$

Результати розрахунку експериментальних даних наведені в табл. 1. Отримані дані дають змогу зробити висновок про сумарну ефективність компонентів, які входять до складу складних сумішей природного походження без їх попереднього розділення.

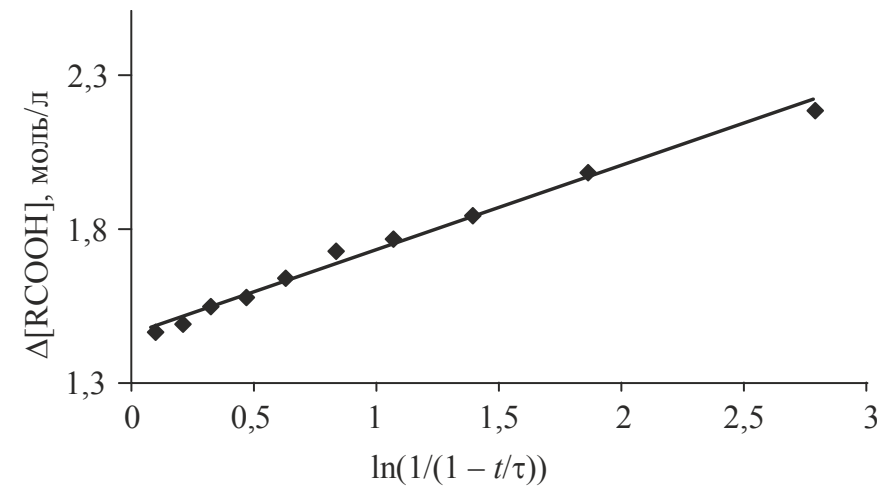

Рис. 2. Залежність швидкості окиснення $\ln \frac{1}{1-t / \tau}$

(на прикладі горіхової пресової олії) 
Таблиия 1. Кінетичні параметри окиснення досліджуваних олій

\begin{tabular}{|c|c|c|c|c|}
\hline Зразок олії & $\begin{array}{c}\text { Сумарна } \\
\text { ефективна } \\
\text { концентрація } \\
\text { антиоксидантів } \\
f[\mathrm{InH}] \cdot 10^{3}, \text { моль/г }\end{array}$ & $\begin{array}{c}\text { Антирадикальна } \\
\text { активність } \\
\left(k_{2} / k_{7}\right) \cdot 10^{2}, \\
(\text { л/моль } \cdot \text { с) }\end{array}$ & $\begin{array}{c}\text { Швидкість } \\
\text { ініціювання } \\
V_{i} \cdot 10^{5}, \\
\text { моль/(л } \cdot \text { с) }\end{array}$ & $\begin{array}{c}\text { Період } \\
\text { індукціі } \tau, \text { хв }\end{array}$ \\
\hline $\begin{array}{c}\text { Соняшникова } \\
\text { пресова }\end{array}$ & 4,7 & 2,82 & 1,79 & 14,2 \\
\hline Горіхова пресова & 5,5 & 2,07 & 1,25 & 15,3 \\
\hline Гірчична пресова & 25,6 & 1,55 & 0,65 & 27,5 \\
\hline Ріпакова пресова & 3,1 & 3,97 & 2,50 & 11,8 \\
\hline $\begin{array}{c}\text { Оливкова } \\
\text { рафінована }\end{array}$ & 5,5 & 2,76 & 1,29 & 15,0 \\
\hline $\begin{array}{c}\text { Кукурудзяна } \\
\text { рафінована } \\
\text { дезодорована }\end{array}$ & 34,6 & 1,88 & 1,39 & 17,8 \\
\hline
\end{tabular}

Найкращі кінетичні параметри мають гірчична та кукурудзяна олії: значення констант $k_{p 2} / k_{7}$ дорівнює 1,55 та 1,88 відповідно, що вказує на превалювання швидкості реакції обривання ланцюгів окиснення на молекулах інгібітора над реакціями подовження. Порівняння інгібуючої дії окремих олій за періодом індукції $\tau$, показало, що найбільш тривалу дію проявляють антиоксиданти гірчичної пресової і кукурудзяної рафінованої дезодорованої олій. Швидкість ініціювання під час автоокиснення олій визначається вмістом антиокиснюючих речовин (за інших однакових умов), насамперед вмістом природних антиоксидантів [6-8].

Якщо прийняти, що $f=2$ (стехіометничний коефіцієнт інгібірування для токоферолу), то розрахована сумарна ефективна концентрація антиоксидантів добре узгоджується з вмістом у рослинних оліях токоферолів, визначених іншими методами [9]. Тому можна висунути припущення, що всі досліджувані олії містять токофероли. Токофероли за своєю антирадикальною дією $\epsilon$ інгібіторами радикальних процесів, характерною рисою яких є утворення достатньо активних радикалів In, здатних брати участь у реакціях продовження ланцюгів.

Для визначення вмісту токоферолів, що є природними інгібіторами ланцюгових процесів, використовували метод рідинної хроматографії високороздільної здатності [10]. Результати досліджень представлено у табл. 2.

\section{Таблиия 2. Вміст токоферолів у зразках досліджуваних олій}

\begin{tabular}{|c|c|c|c|c|c|}
\hline \multirow{2}{*}{ Зразок олії } & \multirow{2}{*}{$\begin{array}{c}\text { Загальний } \\
\text { вміст, мг \% }\end{array}$} & \multicolumn{3}{|c|}{ Ізомери, \% загального } & \multirow{2}{*}{$\begin{array}{c}\text { Сумарний вміст, мг \%, } \\
\text { (за Codex Alimentarius) }\end{array}$} \\
\cline { 3 - 6 } & 2 & $\alpha$ & $\beta$ & $\gamma+\delta$ & 6 \\
\hline 1 & 95 & 91,5 & 8,5 & - & $40,3-102,1$ \\
\hline Соняшникова пресова & 109 & 46,4 & 48,0 & 5,6 & $56,0-113,0$ \\
\hline Горіхова пресова & 84 & 26,3 & 71,3 & 2,4 & $34,0-90,2$ \\
\hline Гірчична пресова & & \multicolumn{3}{|c|}{} \\
\hline
\end{tabular}




\begin{tabular}{|c|c|c|c|c|c|}
\hline \multicolumn{1}{|c|}{} & \multicolumn{4}{c}{ Продовження табл. 2 } \\
\hline 1 & 2 & 3 & 4 & 5 & 6 \\
\hline Ріпакова пресова & 56 & 27 & 73 & - & $28,9-130,1$ \\
\hline Оливкова рафінована & 109 & 46,4 & 48,0 & 5,6 & $56,0-113,0$ \\
\hline $\begin{array}{c}\text { Кукурудзяна } \\
\text { рафінована } \\
\text { дезодорована }\end{array}$ & 655 & 49,1 & 42,4 & 8,5 & $31,4-347,2$ \\
\hline
\end{tabular}

Аналізуючи дані табл. 1 і 2, можна стверджувати, що загальний вміст токоферолів у досліджуваних оліях добре корелює зі значенням сумарної ефективної концентрації антиоксидантів. Наприклад, найвищий їх вміст (655 мг\%) виявлено в кукурудзяній олії, яка відрізняється найвищою сумарною ефективною концентрацією антиоксидантів $\left(34,6 \cdot 10^{3}\right.$ моль/г). Подібна тенденція зберігається для всіх досліджених олій, за винятком гірчичної. Гірчична олія повільно накопичує гідропероксиди в реакції автоокиснення та відзначається високою сумарною концентрацією антиоксидантів на рівні $25,6 \cdot 10^{3}$ моль/г. На нашу думку, високу стабільність гірчичної олії можна пояснити наявністю інших видів антиоксидантів, зокрема фенольної природи. Для перевірки цієї гіпотези було проведено якісне визначення летких сполук методом розгонки.

Вміст легколетких компонентів, визначений хроматографією високороздільної здатності, показав наявність $\alpha$-пінену та 1,8 -цинеолу серед компонентів гірчичної олії (рис. 3). Ці сполуки належать до монотерпенів, що складають ароматичні фракції ефірних олій. Очевидно, терпени переходять у жирну олію під час технологічних операцій отримання.

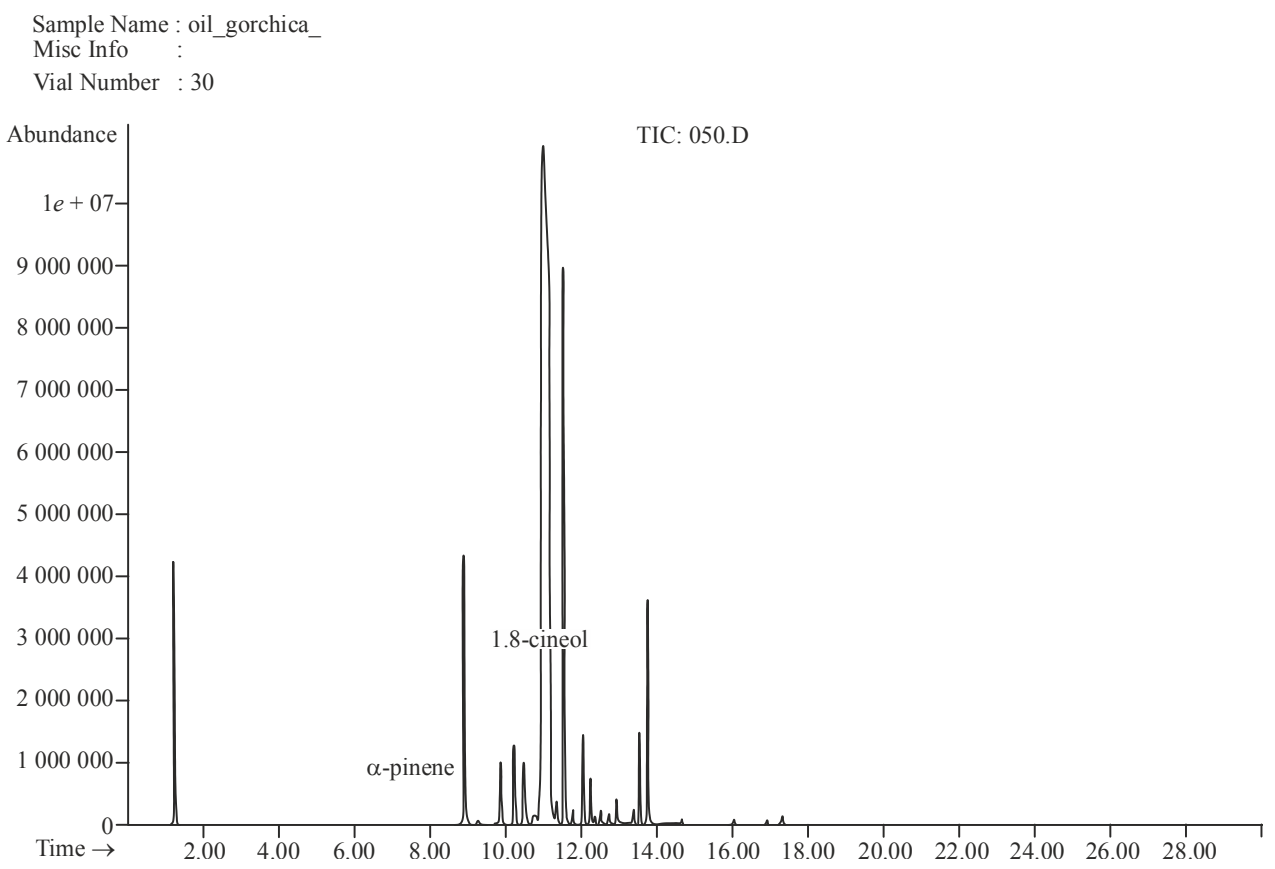

Рис. 3. Хроматограма легколетких компонентів гірчичної олії 
$\alpha$-пінен $\mathrm{C}_{10} \mathrm{H}_{16}$ належить до групи біциклічних терпенових вуглеводнів, входить до складу багатьох ефірних олій, зокрема хвойних і цитрусових. Завдяки властивості швидко окиснюватись на повітрі, особливо при доступі світла, пінен здатний вступати в реакції обривання ланцюгів окиснення, таким чином уповільнюючи його.

Цинеол $\mathrm{C}_{10} \mathrm{H}_{18} \mathrm{O}$ - моноциклічний терпен 3 характерним запахом $\mathrm{i}$ пекучим смаком, зустрічається у складі евкаліптової, лаврової, м'ятної, ялицевої ефірних олії. Чистий рідкий цинеол, вилучений з евкаліптової олії гідродистиляцією, застосовується в медицині і косметології як антисептик. Відрізняється високою активністю щодо вільних радикалів і здатний до їх інактивації, чим і пояснюється його антирадикальна активність.

Тож сукупність активних компонентів, що містяться в олії гірчиці сарептської, обумовлює ії високу біологічну цінність і використання як дієтичного продукту харчування.

\section{Висновки}

У статті вперше обчислено константи швидкості ініціювання й обривання ланцюгів окиснення для двох типів природних антиоксидантів у гірчичній пресовій олії. В процесі зберігання за температури $22 \pm 2^{\circ} \mathrm{C}$ з вільним доступом світла спостерігається значне виснаження вмісту антиоксидантів, що проявляється прискоренням процесу пероксидації.

Показано, що ефективні концентрації антиоксидантів та їхня антирадикальна активність інформативні в плані оцінки ефективності продукту як носія антиоксидантів, але недостатні для оцінки стійкості продукту до окиснювальних змін.

Подальший напрямок досліджень вбачається у вивченні поведінки антиоксидантного комплексу пресової гірчичної олії в умовах термічного окиснення в складі модельних систем харчових продуктів на основі сировини тваринного і рослинного походження.

\section{Література}

1. Ghosh V.L. Mustard oil vicroemulsion formulation and evaluation of bactericidal activity / Vijaya Lakshmi Ghosh, Amitava Mukherjee, N. Chandraseka Ran // International Journal of Pharmacy and Pharmaceutica. 1 Sciences. - 2012. - Vol 4, Issue 4. P. 497-500.

2. Langenbeck W.Autoxidationofsaturatedhydrocarbonsinliquidphase / W. Langenbeck, W. Pritskov // Chem. Techn. — 1952. — \# 4. - P. 391-396.

3. Pritskov W. UberdieAutoxidationvanketonen / W. Pritskov // Chem. Ber. — 1954. — V. 87. — P. $1668-1672$.

4. Денисов E.T. Механизм жидкофазного окисления кислородсодержащих соединений / Е.Т. Денисов, В.И. Мицкевич, В.Е. Агабеков. - Минск : Наука, 1975. — 336 с.

5. Семенов Н.Н. О некоторых проблемах химическойкинетики и реакционной способности / Н.Н. Семенов. — Москва : Изд. АН СССР, 1958. — 685 с.

6. Гусева Д.А. Антиоксидантная активность растительных масел с разным соотношением омега-6/омега-3 жирных кислот / Д.А. Гусева, Н.Н. Прозоровская, А.В. Широнин, М.А. Санжаков, Н.М. Евтеева, И.Ф. Русина, О.Т. Касаикина // Биомедицинская химия. 2010. - T. 56, № 3. - C. 342-350. 
7. Lampe J.W. Diet, geneticpolymorphisms, detoxicationandhealthrisks / J.W. Lampe // Alternative therapies inhealthand medicine. - 2007. - V.13, \# 3. - P. 108-111.

8. Branscheid W. LangkettigeFettsäurenbeiRindfleisch-kritischbewertet / W. Branscheid // Mitteilungsblattder Fleischforschung, Kulmbach. — 2008. — \# 180. — P. 120.

9. Іванов С.В. Технологія купажованих жирів збалансованого жирнокислотного складу : Монографія / С.В. Іванов, Л.В. Пешук, І.Г. Радзієвська. - Київ : НУХТ, 2013. $210 \mathrm{c}$.

10. Храпова Н.Г. Кинетические характеристики природних антиоксидантов растительных масел / Н.Г. Храпова, И.П. Скибида, В.М. Мисин // Химическая физика. — 2010. T. 29, № 6. - C. 76-80.

11. Bozhko N., Tischenko V., Pasichnyi V., Marynin A., Polumbryk M. (2017). Analysis of the influence of rosemary and grape seed extracts on oxidation the lipids of Peking duck meat. Eastern-European Journal of Enterprise Technologies. 4/11 (88), 4 9. doi: 10.15587/17294061.2017.108851.

12. Ukrainets A.I. (2016). Antioxidant plant extracts in the meat processing industry. Biotechnologia Acta, 9 (2), 19-27. doi: 10.15407/ biotech9.02.019. 